\title{
Reconnoitering the Role of Long-Noncoding RNAs in Hypertrophic Cardiomyopathy: A Descriptive Review
}

\author{
Syeda K. Shahzadi ${ }^{1}$, Nerissa Naidoo ${ }^{1, *}$, Alawi Alsheikh-Ali ${ }^{1,2}$, Manfredi Rizzo ${ }^{3}$ (D) Ali A. Rizvi ${ }^{4}$ (D, \\ Raul D. Santos ${ }^{5}$ and Yajnavalka Banerjee ${ }^{1,6, *(D)}$
}

1 Department of Basic Medical Sciences, Mohammed Bin Rashid University of Medicine and Health Sciences, Dubai 505055, United Arab Emirates; Syeda.Shahzadi@mbru.ac.ae (S.K.S.); alsheikhali@gmail.com (A.A.-A.)

2 Dubai Health Authority, Dubai 66566, United Arab Emirates

3 Department of Health Promotion Sciences, Maternal and Infantile Care, Internal Medicine and Medical Specialties (PROMISE), University of Palermo, 90127 Palermo, Italy; manfredi.rizzo@unipa.it

4 Division of Endocrinology, Metabolism, and Lipids, School of Medicine, Emory University, Atlanta, GA 30322, USA; ali.abbas.rizvi@emory.edu

5 The Heart Institute, Faculty of Medicine, University of São Paulo, São Paulo 01000, Brazil; rauldsf@gmail.com

6 Centre of Medical Education, School of Medicine, University of Dundee, Dundee DD1 4HN, UK

* Correspondence: Nerissa.Naidoo@mbru.ac.ae (N.N.); Yajnavalka.Banerjee@mbru.ac.ae (Y.B.); Tel.: +971-4383-8728 (N.N.); +971-4383-8710 (Y.B.)

check for updates

Citation: Shahzadi, S.K.; Naidoo, N.; Alsheikh-Ali, A.; Rizzo, M.; Rizvi,

A.A.; Santos, R.D.; Banerjee, Y.

Reconnoitering the Role of

Long-Noncoding RNAs in

Hypertrophic Cardiomyopathy: A Descriptive Review. Int. J. Mol. Sci. 2021, 22, 9378. https://doi.org/ $10.3390 /$ ijms 22179378

Academic Editor: Christian Jung

Received: 17 June 2021

Accepted: 12 August 2021

Published: 29 August 2021

Publisher's Note: MDPI stays neutral with regard to jurisdictional claims in published maps and institutional affiliations.

Copyright: (c) 2021 by the authors. Licensee MDPI, Basel, Switzerland. This article is an open access article distributed under the terms and conditions of the Creative Commons Attribution (CC BY) license (https:// creativecommons.org/licenses/by/ $4.0 /)$.

\begin{abstract}
Hypertrophic cardiomyopathy (HCM) is the most common form of hereditary cardiomyopathy. It is characterized by an unexplained non-dilated hypertrophy of the left ventricle with a conserved or elevated ejection fraction. It is a genetically heterogeneous disease largely caused by variants of genes encoding for cardiac sarcomere proteins, including MYH7, MYBPC3, ACTC1, TPM1, MYL2, MYL3, TNNI3, and TNNT23. Preclinical evidence indicates that the enhanced calcium sensitivity of the myofilaments plays a key role in the pathophysiology of HCM. Notably, this is not always a direct consequence of sarcomeric variations but may also result from secondary mutation-driven alterations. Long non-coding RNAs (lncRNAs) are a large class of transcripts $\geq 200$ nucleotides in length that do not encode proteins. Compared to coding mRNAs, most lncRNAs are not as well-annotated and their functions are greatly unexplored. Nevertheless, increasing evidence shows that lncRNAs are involved in a variety of biological processes and diseases including HCM. Accumulating evidence has indicated that lncRNAs are dysregulated in HCM, and closely related to sarcomere construction, calcium channeling and homeostasis of mitochondria. In this review, we have summarized the known regulatory and functional roles of lncRNAs in HCM.
\end{abstract}

Keywords: hypertrophic cardiomyopathy; long non-coding RNA; genetic variants; cardiovascular diseases

\section{Introduction}

Hypertrophic cardiomyopathy $(\mathrm{HCM})$ is one of the most prevalent inherited disorders of cardiomyocytes, without specific geographic, ethnic, or sex patterns of distribution. Studies estimate a prevalence of HCM at a range between $0.16-0.29 \%(\sim 1: 625$ to 1:344 individuals) in the general adult population [1]. HCM is categorized as a typical single gene disorder with variable penetrance and expression, exhibiting an autosomal dominant pattern of inheritance. More than 1500 gene variants have been linked to HCM, with over $95 \%$ of them found in 11 or more genes encoding sarcomeric proteins, the heart's contractile building blocks [2]. Variants of HCM with autosomal recessive and X-linked modes of inheritance have been described but are rare [3,4].

Phenotypically, HCM is characterized by an increase in the left ventricular wall thickness (end-diastolic left ventricular wall thickness $\geq 15 \mathrm{~mm}$ or the equivalent relative to the body surface area in children that cannot be solely explained by abnormal loading conditions (European Society of Cardiology Guidelines) [5]. Ventricular wall thickness to 
lesser degrees (13-14 mm) can also be diagnostic of HCM, especially when it is identified in family members [6]. Additionally, cardiac hypertrophy observed in HCM is typically asymmetric, with the greatest involvement most commonly at the basal interventricular septum subjacent to the aortic valve (Figure 1A). It is infrequently restricted to other myocardial regions, such as the posterior wall of the left ventricle in symmetric hypertrophy (Figure 1B) and at the apex in apical hypertrophy (Figure 1C).
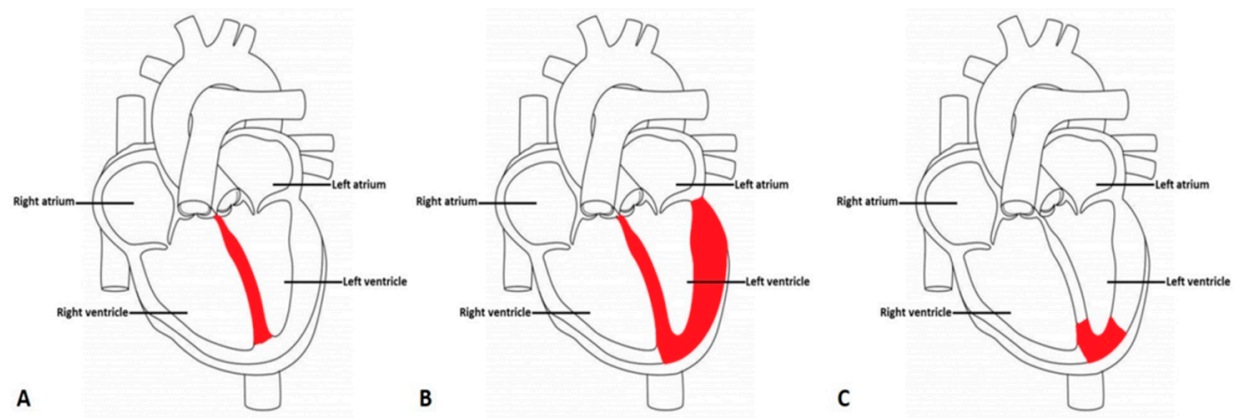

Figure 1. Variant Morphological Patterns of Hypertrophic Cardiomyopathy (A) Asymmetric Septal Hypertrophy with or without obstruction: asymmetric involvement of the interventricular septum where the stiffened, thickened area is shaded in red. (B) Symmetric or Concentric Hypertrophy: symmetrical stiffening and thickening of the left ventricle in a circumferential pattern shaded in red. (C) Apical Hypertrophy: stiffening and thickening of the apex of the left ventricle shaded in red.

Estimating the prevalence of HCM based on clinical detection of cardiac hypertrophy has many limitations. The first issue lies with age-dependent expression of cardiac hypertrophy, present in almost one-half and approximately three-fourths of patients with underlying contributing variants by the third and sixth decades of life, respectively. Due to the age-dependent expression of HCM variants, it is expected that its prevalence will be higher in the elderly. Attesting to this is the fact that HCM has been documented in $0.29 \%$ (1:333) of 60-year-old subjects undergoing echocardiography for cardiovascular evaluation in the United States, United Arab Emirates and in other parts of the globe [7-10]. Furthermore, when more sensitive imaging methods are used, or when more family members from a family diagnosed with HCM are evaluated clinically and through genetic testing, a much higher estimate of $0.6 \%(1: 167)$ has been proposed [11-13]. This warrants that the mechanism underlying HCM be investigated at depth to identify novel biomarkers, allowing for an uncomplicated diagnosis of the condition. Accurate estimates can thus be obtained, facilitating the development of suitable therapeutic and management strategies.

Long non-coding RNAs (lncRNAs) have transcripts $\geq 200$ nucleotides that do not code for proteins. In comparison to messenger (m) RNAs, lncRNAs are less well-annotated, and their role in the physiological milieu remains largely unexplored. Increasing evidence shows that lncRNAs are implicated in causation of HCM. However, a comprehensive review evaluating the link/association of lncRNA with HCM is currently absent in the literature. In this manuscript, we address this gap of information. First, we provide the reader with an overview of HCM, focusing on the molecular genetic aspects. Next, we elaborate on lncRNAs' role in a variety of pathophysiological states focusing on HCM. Lastly, we identify areas of further research that still need to be addressed such that lncRNAs can be effectively employed as novel biomarkers for the early detection and suitable management of HCM.

\section{Molecular Genetics of HCM}

Based on several identified variants in major causal genes and all encoding sarcomere proteins, HCM is classified as a genetically heterogeneous condition. HCM patients are found to have some sort of genetic mutation in one-half of the cases on average [14,15]. Genetic dissection of HCM patients has revealed a series of alterations in more than 11 gene encoding sarcomeric proteins [16]. HCM follows the dominant autosomal inheritance 
pattern with variable penetrance and expression related to age or as a new variation in nonrelated family cases [17]. The most dominant mutation is a missense mutation, replacing one nucleic acid with another, resulting in the modification of the translated amino acid and subsequent protein. Deletions and insertions are also found to be common in the pathogenesis of HCM leading to the translation of a modified protein [18].

Most variations occur in genes that are responsible for normal functioning of contractile sarcomeric proteins: troponin I and $\mathrm{T}$, myosin binding protein $\mathrm{C}$, myosin heavy and light chains, $\alpha$-actin, titin and $\alpha$-tropomyosin. Nevertheless, in rare cases, variations in non-sarcomeric protein coding genes have also been reported in HCM patients [19]. The genes predominantly related to the HCM development are TNNT2, MYH7, MYBPC3, ACTC1, TPMI, TNNI3, TNNC1, TNNC2, MYL2, MYL3, CSRP3, and MYOZ2 (Figure 2 and Table 1) [20].

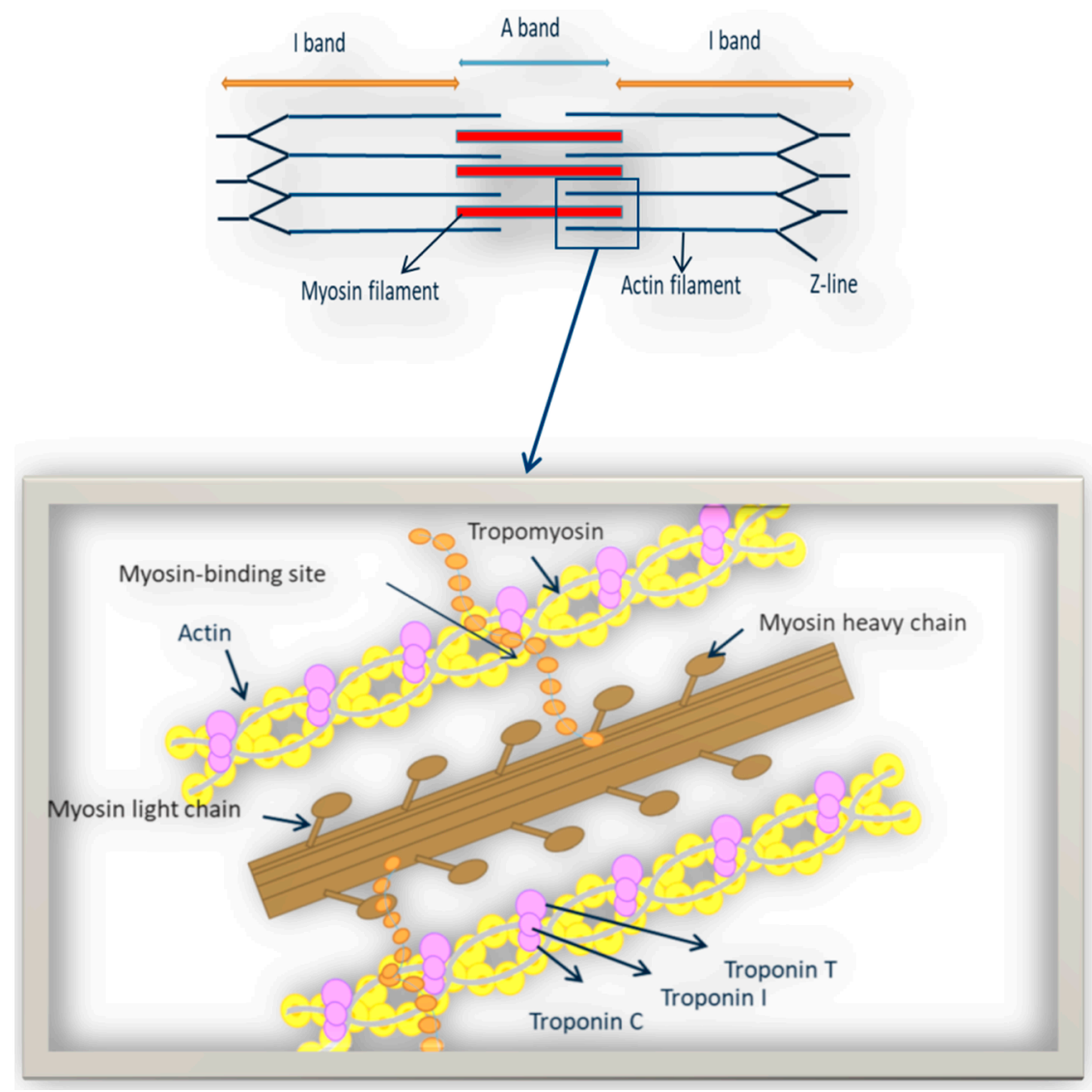

Figure 2. Representation of sarcomeric proteins responsible for expression of HCM.

The MYH7 and MYBPC3 (myosin-binding protein C) genes are the most prevalent and are recognized to be responsible for approximately $50 \%$ of patients with familial HCM [21,22]. Variants TNNT2, TNNI3 (cardiac troponin I) and TPM1 ( $\alpha$-tropomyosin) are comparatively infrequent causes of HCM and account for $<10 \%$ of all cases $[23,24]$. Variations in ACTC1 (cardiac $\alpha$-actin), MYL2 (myosin light chain 2), MYL3 (myosin light chain 3) and CSRP3 (cysteine and glycine-rich protein 3) are also found to cause HCM [25,26]. While variations in TCAP (telethonin) [27], TTN (titin) [28], MYOZ2 (myozenin 2), FHL1 (four-and-a-half LIM domains 1) [29], and TRIM63 (ubiquitin E3 ligase tripartite protein 63 or MuRF1) usually occur in rare cases and small families [30].

The concept of phenocopies within the HCM setting is also vital to highlight. These patients might have a HCM phenotype without the reported HCM genetic variants, but often present are a few other diseases driving to a similar heart condition, such as LAMP2 cardiomyopathy, Fabry malady, PRKAG2, Pompe Disease, Noonan syndrome, 
Wolff-Parkinson-White syndrome, Barth syndrome, Forbes disease, and/or amyloidosis (Table 2) [31].

Table 1. List of genes implicated in hypertrophic cardiomyopathy.

\begin{tabular}{|c|c|c|c|c|c|}
\hline Gene & Protein & Location & Function & Locus & Frequency (\%) \\
\hline ACTC1 & Cardiac actin-1 & \multirow{5}{*}{ Thin Filament } & Actomyosin interaction & $15 q 14$ & $<1$ \\
\hline TPMI & $\alpha$-tropomyosin & & $\begin{array}{c}\text { Places the troponin complex on } \\
\text { cardiac actin }\end{array}$ & $15 q 22.2$ & $<1$ \\
\hline TNNI3 & Cardiac troponin I & & $\begin{array}{l}\text { Inhibitor of actomyosin } \\
\text { interaction }\end{array}$ & $19 \mathrm{q} 13.4$ & $<5$ \\
\hline TNNC1 & Cardiac troponin C & & $\begin{array}{l}\text { Calcium sensor in cardiac and } \\
\text { slow skeletal muscle }\end{array}$ & $3 p 21.1$ & $<1$ \\
\hline TNNT2 & Cardiac troponin $\mathrm{T}$ & & $\begin{array}{l}\text { Regulator of actomyosin } \\
\text { interaction }\end{array}$ & $1 \mathrm{q} 32.1$ & $\sim 10$ \\
\hline МҮВРСЗ & $\begin{array}{l}\text { Myosin binding } \\
\text { protein } C\end{array}$ & \multirow{4}{*}{ Thick Filament } & Cardiac contraction & $11 \mathrm{p} 11.2$ & $\sim 40$ \\
\hline MYH7 & $\begin{array}{l}\text { Cardiac myosin heavy } \\
\text { chain } \beta\end{array}$ & & $\begin{array}{l}\text { ATPase activity, force } \\
\text { generation }\end{array}$ & $14 q 11.2$ & $\sim 40$ \\
\hline$M Y L 2$ & $\begin{array}{l}\text { Cardiac myosin light } \\
\text { chain } 2\end{array}$ & & MYH7 binding protein & $12 \mathrm{q} 21.11$ & $<1$ \\
\hline MYL3 & $\begin{array}{l}\text { Cardiac myosin light } \\
\text { chain } 3\end{array}$ & & MYH7 binding protein & $3 p 21.31$ & $<1$ \\
\hline CSRP3 & $\begin{array}{l}\text { Cysteine and glycine } \\
\text { rich protein } 3\end{array}$ & \multirow[t]{2}{*}{ Z-disk } & $\begin{array}{l}\text { Muscle LIM protein (MLP), a Z } \\
\text { disk protein }\end{array}$ & $11 \mathrm{p} 15.1$ & $<1$ \\
\hline MYOZ2 & Myozenin 2 & & $\mathrm{Z}$ disk protein & $4 q 26$ & $<1$ \\
\hline
\end{tabular}

Table 2. Phenocopies of hypertrophic cardiomyopathy.

\begin{tabular}{|c|c|c|c|c|}
\hline Syndrome & Gene & Protein & Locus & Frequency \\
\hline Danon's syndrome & LAMP2 & $\begin{array}{l}\text { lysosome-associated membrane } \\
\text { protein-2 }\end{array}$ & Xq24 & rare \\
\hline $\begin{array}{l}\text { Forbes disease (Glycogen } \\
\text { Storage Disease Type 3) }\end{array}$ & AGL & Amylo-1,6-glucosidase & $1 \mathrm{p} 21$ & rare \\
\hline $\begin{array}{l}\text { Fabry's disease (Lysosomal } \\
\text { Storage Disorder) }\end{array}$ & GLA & a-Galactosidase A & $\mathrm{Xq} 22$ & $<5 \%$ \\
\hline $\begin{array}{l}\text { Pompe Disease (Glycogen } \\
\text { Storage Disease Type 2) }\end{array}$ & GAA & a-1,4-glucosidase deficiency & 17q25.2-q25.3 & rare \\
\hline $\begin{array}{c}\text { Noonan } \\
\text { syndrome/LEOPARD } \\
\text { syndrome }\end{array}$ & $\begin{array}{l}\text { PTPN11 } \\
\text { SOS1 } \\
\text { RAFI }\end{array}$ & $\begin{array}{c}\text { v-Ki-ras2 Kirsten rat sarcoma viral } \\
\text { oncogene } \\
\text { Homolog } \\
\text { Son of sevenless homolog } 1 \\
\text { V-RAF-1 murine leukemia viral } \\
\text { oncogene homolog } 1\end{array}$ & $\begin{array}{l}12 q 24.1 \\
2 \mathrm{p} 22-\mathrm{p} 21 \\
3 \mathrm{p} 25\end{array}$ & $\begin{array}{l}\text { rare } \\
\text { rare }\end{array}$ \\
\hline Friedreich's ataxia & FXN & Frataxin & $9 q 13$ & rare \\
\hline $\begin{array}{l}\text { Wolff-Parkinson-White } \\
\text { syndrome }\end{array}$ & PRKAG2 & AMP-activated protein kinase & 7q35-q36.36 & $<1 \%$ \\
\hline $\begin{array}{c}\text { Barth syndrome/left } \\
\text { ventricular noncompaction }\end{array}$ & $\begin{array}{l}\text { DTNA } \\
\text { TAZ }\end{array}$ & $\begin{array}{l}\text { a-Dystrobrevin } \\
\text { Tafazzin (G4.5) }\end{array}$ & $\begin{array}{l}18 \mathrm{q} 12 \\
\mathrm{Xq} 28\end{array}$ & rare \\
\hline
\end{tabular}




\section{Molecular and Biological Functions of lncRNAs}

Long non-coding RNAs (lncRNAs) are characterized as RNAs having a transcript length that surpasses $200 \mathrm{bp}$ of nucleotides and are not decoded into proteins [32]. Although lncRNAs were once thought to be byproducts of RNA polymerase II transcripts without any specific biological function, an expansive collection of lncRNAs have been certified to modulate cellular processes, such as genome and chromosome and modification, nuclear transport and transcription stimulation, hence driving more analysts to investigate how lncRNAs impact human biology. Classification of lncRNAs can be done in terms of function, location, length, and mode of action and as of now there's no single standard for their categorization. Agreeing to their position within the genome, they can be categorized as sense, antisense, bidirectional, intronic, intergenic, and enhancer lncRNAs [33]. At the same time, they are commonly sorted as bait, scaffold, signal, and guide lncRNAs according to their functional mechanisms [34]. Recent studies reported that lncRNAs can translate small peptides to fine-tune common processes in a tissue-specific way, further disclosing the esteem of lncRNAs as well as their complexity [35-38]. However, the modes in which IncRNAs modulate gene expression are complicated and therefore, have not been completely explained. LncRNAs can work through diverse modes of operations: (1) binding to transcription factors or DNA directly to attain gene expression control at the transcriptional level; (2) focusing on miRNAs, mRNAs, and proteins to regulate their activities at the posttranscriptional level and (3) intertwining with chromatin complexes to modulate epigenetic gene expression [39-41].

The mode of action of lncRNAs permits their presence in nearly all physiological processes in living cells, thus relating them to a broad range of diseases. LncRNAs have developed into potent novel molecules in disease prognosis, diagnosis and treatment. As a result of their crucial role in diseases, researchers are presently developing tools and technologies to make lncRNA-based drugs by targeting lncRNAs. The relationship between chronic diseases and IncRNAs is explicit. In any case, cancer is the foremost studied illness that is related to lncRNAs [42]. However, recent years has revealed accounting evidence that has emphasized the role of lncRNA modulation in cardiovascular development as well as in cardiovascular diseases [43]. A thorough functional characterization of lncRNAs may help in the monitoring, prevention and treatment of cardiovascular diseases, including cardiac hypertrophy, hypertension, myocardial infarction and heart failure. Recent studies show that IncRNA-DACHI modulates heart function, and it was upregulated in heart failure patients, whereas the knockdown of lncRNA-DACHI in Heart failure (HF) mice hampered the HF development [44]. LncRNA-Safe was found to promote myocardial fibrosis and its inhibition in fibroblasts impeded cardiac functions: showing that the Safe can be a novel target for antifibrotic therapy [45]. Until now, MHRT, CHRF, MALATA1 and many more lncRNAs have been investigated in the cardiovascular field, particularly in cardiac hypertrophy (Table 3) [33]. However, the functions of lncRNAs in diagnosis, prevention and treatment of $\mathrm{HCM}$ are still understudied and should be further explored to identify novel biomarkers for HCM.

Table 3. LncRNAs involved in pathogenesis of Cardiac Hypertrophy.

\begin{tabular}{cl}
\hline lncRNA & \multicolumn{1}{c}{ Mechanism of Action } \\
\hline Plscr4 & Protective against cardiac hypertrophy by sponging miR-214 to derepress Mfn2 [46] \\
\hline Chast & $\begin{array}{l}\text { Promotes cardiac hypertrophy by activating NFAT signaling and downregulates Plekhm1 to induce } \\
\text { cardiac remodeling processes [47] }\end{array}$ \\
\hline CHRF & $\begin{array}{l}\text { Induces cardiac hypertrophic response by sponging miR-489 to increase expression of Myd88, also by } \\
\text { sponging miR-93 to disinhibit PI3K/Akt pathway [48] }\end{array}$ \\
\hline MIAT & $\begin{array}{l}\text { Contributing factor to the pathogenesis of cardiac hypertrophy and act by } \\
\text { 1-Sponging miR-150 to increase expression of P300 [49,50] } \\
\text { 2-Sponging miR-93 to activate PI3K/Akt/mTOR pathway via TLR4 [49] }\end{array}$ \\
\hline
\end{tabular}


Table 3. Cont.

\begin{tabular}{|c|c|}
\hline lncRNA & Mechanism of Action \\
\hline Chaer & $\begin{array}{l}\text { Increases pro-hypertrophic gene expression by interacting with PCR2 to disinhibit hypertrophic gene } \\
\text { expression [51] }\end{array}$ \\
\hline HOTAIR & Inhibits progress of cardiac hypertrophy by sponging miR-19 to derepress PTEN expression [52] \\
\hline ROR & Promotes fetal genes and cardiomyocyte growth by sponging miR-133 [53] \\
\hline MAGI1-IT1 & $\begin{array}{l}\text { Protects against cardiac hypertrophy by sponging miR-302e to derepress DKK1 and inactivate } \\
\text { Wnt/beta-catenin signaling [54] }\end{array}$ \\
\hline Meg3 & Promotes cardiac hypertrophy by activating STAT3 to sponge miR-361-5p and derepress HDAC9 [55] \\
\hline SYNE1-AS1 & $\begin{array}{l}\text { Promotes cardiac hypertrophy and activate SP1 to sponge miR-525-5p to derepress SP1, forming a } \\
\text { positive feedback loop [56] }\end{array}$ \\
\hline MALATI & $\begin{array}{l}\text { Protects against cardiac hypertrophy by sponging miR-302e to derepress DKK1 and inactivate } \\
\text { Wnt/beta-catenin signaling }[57,58]\end{array}$ \\
\hline Ak045171 & $\begin{array}{l}\text { Promotes cardiac hypertrophy by binding with SP1, which promotes transcription activation of } \\
\text { MEG3 [59] }\end{array}$ \\
\hline TINCR & Attenuates cardiac hypertrophy by epigenetically silencing CaMKII [60] \\
\hline UCA1 & $\begin{array}{l}\text { Promotes the progression of cardiac hypertrophy through competitively binding with miR-184 to } \\
\text { enhance the expression of HOXA9 [61] }\end{array}$ \\
\hline XIST & $\begin{array}{l}\text { 1-Regulates cardiac hypertrophy by sponging miR-101 to derepress TLR2 [62] } \\
\text { 2-Attenuates cardiac hypertrophy by sponging miR-330-3p to derepress S100 [63] }\end{array}$ \\
\hline TUG1 & $\begin{array}{l}\text { 1-Contributes to cardiac hypertrophy via regulating miR-29b-3p [64] } \\
\text { 2-Alleviates cardiac hypertrophy by targeting miR-34a/DKK1/Wnt- } \beta \text {-catenin signaling [65] }\end{array}$ \\
\hline VDR/CASC15 & Facilitates cardiac hypertrophy via miR-432-5p/TLR4 axis [66] \\
\hline CYTOR & $\begin{array}{l}\text { Protects against cardiac hypertrophy through miR-155 and downstream IKKi and NF- } \mathrm{kB} \\
\text { signaling [67] }\end{array}$ \\
\hline FTX & $\begin{array}{l}\text { Reduces hypertrophy by regulating the pten/pi3k/akt signaling pathway by sponging } \\
\text { microrna-22 [54] }\end{array}$ \\
\hline PVT1 & Positively regulates cardiac hypertrophy by an unknown mechanism [68] \\
\hline CHAR & $\begin{array}{l}\text { Protects against cardiac hypertrophy via regulating miR-20b and the downstream PTEN/AKT } \\
\text { pathway [69] }\end{array}$ \\
\hline KCNQ1OT1 & Attenuates cardiac hypertrophy through modulation of the miR-2054/AKT3 axis [70] \\
\hline ZEB2-AS1 & Stimulates cardiac hypertrophy by downregulating PTEN [71] \\
\hline PEG10 & Aggravates cardiac hypertrophy by positively regulating HOXA9 [72] \\
\hline NEAT & Promotes cardiac hypertrophy through sponging microRNA-19a-3p/SMYD2 axis [73] \\
\hline Ahit & Protects against cardiac hypertrophy through suz12 -mediated downregulation of mef2a [74] \\
\hline Gm15834 & Alleviates autophagy-induced myocardial hypertrophy by sponging miR-30b-3p [75] \\
\hline
\end{tabular}

\section{Emerging Role of IncRNAs in Pathogenesis of HCM}

Numerous studies demonstrate that lncRNAs regulate pathophysiological processes in cardiac hypertrophy by interacting with genes involved in mitochondria, sarcomeres, and calcium transition at the intracellular level (Table 3). Many review articles have been published on the recent advancement in establishing the role of lncRNA in physiological cardiac hypertrophy [76-80]. However, there is a dearth of research regarding the function of lncRNAs in the pathophysiology of hypertrophic cardiomyopathy (Table 4).

Current evidence suggests that IncRNAs could be a promising target for attenuating or even reversing the pathological phenotype of hypertrophic cardiomyopathy. To date, several animal experiments and bioinformatics analyses have been conducted to determine the possible role of specific lncRNAs in the production of hypertrophic cardiomyopathy. 
However, we focused on those studies only involving the known mechanism of action of lncRNAs in development of hypertrophic cardiomyopathy.

Table 4. LncRNAs involved in pathogenesis of hypertrophic cardiomyopathy.

\begin{tabular}{cl}
\hline IncRNA & \multicolumn{1}{c}{ Mechanism of Action } \\
\hline Mhrt & $\begin{array}{l}\text { Protect against pathological hypertrophic cardiomyopathy by inhibiting the Brg1-Hdac-Parp } \\
\text { chromatin repressor complex to prohibit initiation of Myh6-to-Myh7 switch 2. Reduce myocardin } \\
\text { acetylation/expression via HDAC5 }\end{array}$ \\
\hline MIAT & $\begin{array}{l}\text { Contributing factor to the pathogenesis of hypertrophic cardiomyopathy and act by mediating the } \\
\text { expression of miR-29a-3p }\end{array}$ \\
\hline H19 & $\begin{array}{l}\text { Targets CaMKII } \delta \text { through miR-675 and functions as a negative regulator of hypertrophic } \\
\text { cardiomyopathy }\end{array}$ \\
\hline CAIF & Downregulated in end-stage cardiomyopathy \\
\hline uc004cov.4 & Upregulation leads to Hypertrophic obstructive cardiomyopathy-unknown mechanism \\
\hline uc022bqu.1 & Upregulation leads to Hypertrophic obstructive cardiomyopathy- unknown mechanism \\
\hline
\end{tabular}

\subsection{H19 Regulates HCM through miR-675}

H19 is an lncRNA that is expressed in a variety of tissues and is significantly increased during myoblast differentiation and muscle regeneration. H19 may act as a sponge for several miRNAs, thereby regulating the expression of numerous genes and signaling pathways. In pathological heart failure and cardiac hypertrophy, H19 and its host miR-675 are upregulated. Some researchers identified H19 variants in a group of patients with hypertrophic cardiomyopathy and compared their allele and genotype frequencies to those of healthy controls. In patients without sarcomere variations, the H19 rs2107425 CC genotype was significantly increased ( $p=0.017$; odd ratio: 1.51 ). The H19 transcript sequence revealed heterozygous carriers of a rare allele, rs945977096 AG, that was absent in the controls. Their study established a statistically significant link between H19 variants and an increased risk of developing hypertrophic cardiomyopathy. In pathological HCM and heart failure tissues, H19 and its host miR-675 were upregulated. H19 silencing resulted in cardiomyocyte hypertrophy, while overexpression resulted in cell size reduction both at baseline and in response to phenylephrine, an effect that may be mediated by miR675. The SNP rs2107425 was associated with HCM, with the C allele being significantly more prevalent in patients who did not have sarcomere variants. Thus, homozygotes for rs2107425 CC would have a higher risk of developing HCM [81].

\subsection{LncRNA-MIAT Regulates HCM through miR-29a-3P}

In GC cell lines and tissues, the miR-29a-3p is an important miRNA with poor expression that is regulated by myocardial infarction-associated transcript (MIAT). MIAT can suppress the expression of miR-29a-3p as an endogenous miRNA sponge by making bonds with the miR-29a-3p inside the GC cells. Many studies investigated the expression of MEG3, MIAT, and H19 in effort to identify the particular lncRNA that regulates the miR-29a expression in myocardial fibrosis. Negative correlation of MIAT with the miR-29a expression was discovered. Based on ROC analysis, miR-29a and MIAT may accurately predict the prognosis in HCM patients [82].

\subsection{LncRNA-Mhrt Protects the Myocardium against HCM}

Han et al., identified an important lncRNA transcript cluster from Myh7 loci, which presented a new heart failure mechanism linked with lncRNA-chromatin. They named this transcript as "Myosin Heavy Chain Associated RNA Transcripts (Mhrt or MyHEART)". In the heart, the Brg1-Hdac-Parp chromatin repressor complex3 is activated by pathological stress to inhibit transcription of Mhrt. This stress-induced repression of Mhrt is important for the development of cardiomyopathy: however, Mhrt restoration at a pre-stress level 
protects the heart from hypertrophic cardiomyopathy. In humans, MHRT is also present at MYH7 loci and is found to be suppressing in many kinds of cardiomyopathies, suggesting a conserved lncRNA mechanism in human hypertrophic cardiomyopathy [83].

\subsection{LncRNA-CAIF Attenuates HCM}

Cardiac autophagy inhibitory factor (CAIF) is a unique long noncoding RNA that protects against myocardial infarction. The function of CAIF in end-stage cardiomyopathy was investigated by $\mathrm{Wu}$ et al. This research included patients with end-stage cardiomyopathy and the control subjects. CAIF was found to be downregulated in end-stage cardiomyopathy patients as compared to healthy controls, hence it may be used as a diagnostic and prognostic marker [84]. CAIF expression differentiated patients with end-stage cardiomyopathy from stable controls and predicted patient survival.

\subsection{LncRNAs uc004cov.4 and uc022bqu.1 Mediate HCM}

In another study, seven different cardiac and mitochondrial remodeling-related lncRNAs were quantified in control HOCM and HNCM patients. LncRNAs uc022bqu. 1 and uc004cov.4 were substantially upregulated in patients with HOCM compared to controls, but no substantial deregulation was found in patients with HNCM. In both patients, the lncRNAs uc004coz.1, uc004cos.4, uc022bqw.1, uc011mfi.2, and uc022bqs.1 (LIPCAR) were not deregulated relative to the control group. When ROC curve analysis of the substantially increased lncRNAs in HOCM was conducted, both uc022bqu.1 and uc004cov.4 had the highest potential to considerably classify HOCM patients under the curve area of $>0.68$ [85].

\subsection{High-throughput Screening of IncRNAs in HCM Patients}

Hypertrophic cardiomyopathy (HCM) is one of the most common hereditary heart disorders. However, the signaling pathways and regulatory networks responsible for the manifestation of HCM are poorly understood. Recently, some bioinformatics studies have been done to profile the differentially expressed lncRNAs in HCM patients and to also understand the gene regulatory networks. Case in point, Guo et al. employed weighted correlation network analysis (WCNA) and linear models for microarray data (Limma) to analyze GSE68316 data from cardiac tissue in the Gene Expression Omnibus database. Their analysis did reveal that three circulating lncRNAs (lnc-P2RY6-1:1, ENST00000488040 and ENST00000588047) were significantly upregulated in the HCM cardiac tissue, but they didn't elaborate how these circulating lncRNAs are involved in the molecular mechanism underlying the pathogenesis of HCM. Other similar studies have also been conducted. Readers can refer to these studies for details [86-91].

\section{Probing the Transcriptome for Identification of lnc-RNAs Implicated in HCM}

RNA-seq is an emerging technique in the transcriptome profiling system. Here we present an overview of experimental design and workflow that can be effectively adopted to generate a dedicated protocol, which can be used to identify the differentially expressed lncRNAs in HCM vs. normal heart tissues (Figure 3).

The first and foremost step is the recruitment of HCM patients based on the results of genetic testing for HCM casual genes and collection of their heart tissue through myocardial biopsy. However, this can pose a challenge especially when it comes to obtaining ethical approval, in addition to the fact that myocardial biopsy is a specialized procedure that requires extensive training to perform. One of the ways to bypass this challenge will be to use heart tissue samples obtained from cadavers whose clinical history shows the presence of HCM. Our research group is in the process of standardizing a protocol for isolating total RNA from cadaveric heart tissue samples (Naidoo et al., unpublished data). Total RNA isolated from patients or cadaveric specimens can then be used for the generation of sequencing libraries and resulting libraries can then be sequenced in paired-end mode using a suitable platform such as the Illumina HiSeq system. 
The raw sequencing reads obtained can then be subjected to base quality filtering and adapter trimming. Clean reads thus obtained will then be required to align with the reference genome (Human-GRCh37) using a fast and sensitive alignment program for mapping next-generation sequencing reads.

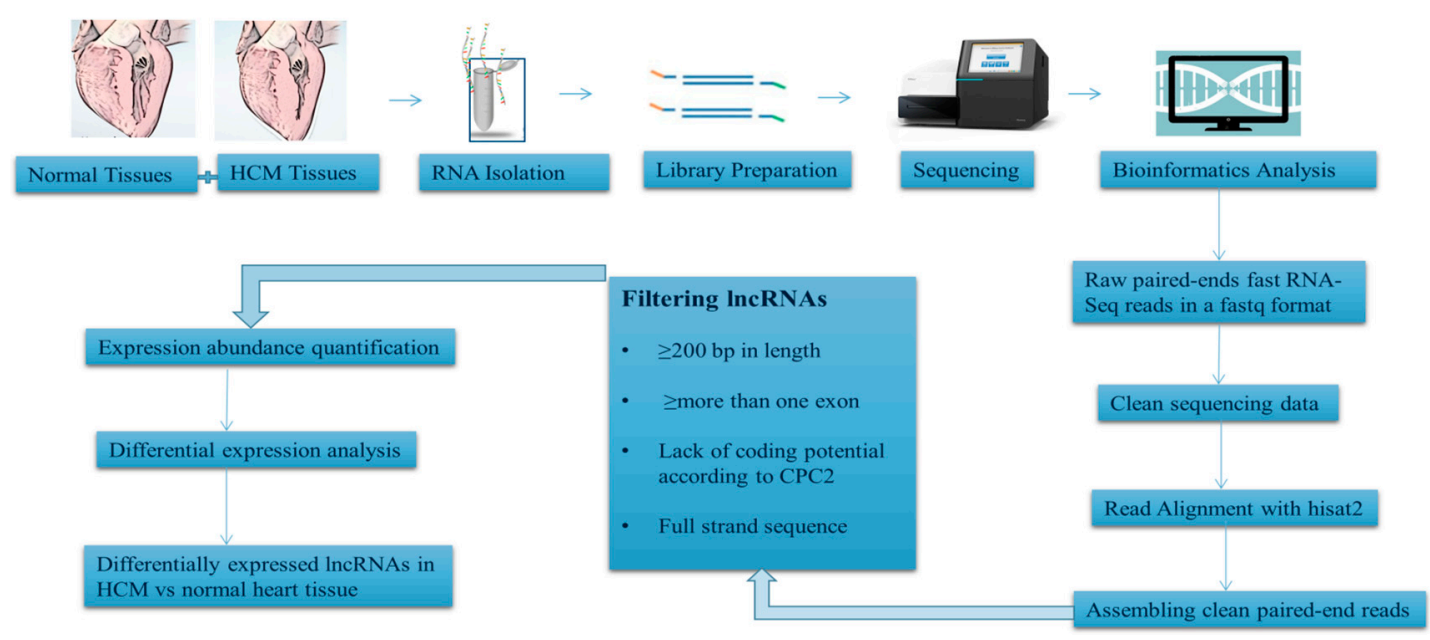

Figure 3. Schematic representation of experimental workflow involved in RNA-seq analysis of differentially expressed lncRNAs in normal and HCM patient's sample.

After assembling all clean paired-end reads, lncRNAs can be filtered according to specific defined criteria: (1) the assembled transcript must have specific strand information: (2) the length should be more than $200 \mathrm{bp}$ : (3) it must have more than one exon and (4) lack of coding potential according to a defined coding potential calculator (CPC) algorithm, such that only the "noncoding" transcripts are obtained as an output.

All long non-coding RNAs will then require incorporation in a differential expression analysis workflow (such as the Stringtie workflow freely accessible on the webpage of The Center for Computational Biology at Johns Hopkins University) leasing to the identification of differentially expressed genes (DEGs). A comparison of DEGs between normal and HCM heart tissues can then be performed using a bioinformatics tool such as sleuth (Readers are requested to refer to the excellent article: Differential analysis of gene regulation at transcript resolution with RNA-seq by Cole Trapnell, David G Henderickson, Martin Savageau, Loyal Goff, John L Rinn and Lior Pachter, Nature Biotechnology 31, 46-53 (2013); where this aspect has been discussed in detail.).

\section{Conclusions}

There has been considerable progression in the molecular mechanisms regarding hypertrophic cardiomyopathy over the past several decades. However, the pathological mechanisms of HCM for improved treatment strategies still require further elucidation. Covering a large body of evidence, this review illustrates that lncRNAs may act as an important participant in the complex network that regulates the pathological process of $\mathrm{HCM}$, identifying them as potentially promising targets for the treatment of hypertrophic cardiomyopathy. It is an emerging avenue in providing new insights to explore the pathophysiologic mechanisms and establishing novel therapeutic targets for disease modulation and prevention.

Author Contributions: S.K.S., N.N. and Y.B. collected literature and prepared the outlines and first draft of manuscript. A.A.-A. reviewed and edited the manuscript. M.R., A.A.R. and R.D.S. gave suggestions and improved the manuscript. All authors have read and agreed to the published version of the manuscript. 
Funding: This study in the form of a descriptive review is supported by an internal grant from MBRU titled "A Thanatogenomic Investigation of the Hydroxymethylome and Mitochondrial Genome of Cadaveric Cardiomyocytes" (MBRU-CM-RG2019-08).

Informed Consent Statement: Not applicable.

Data Availability Statement: Not applicable.

Conflicts of Interest: The authors declare no conflict of interest.

\section{References}

1. Geske, J.B.; Ommen, S.R.; Gersh, B.J. Hypertrophic cardiomyopathy: Clinical update. JACC Hear. Fail. 2018, 6, 364-375. [CrossRef]

2. Viswanathan, S.K.; Sanders, H.K.; McNamara, J.W.; Jagadeesan, A.; Jahangir, A.; Tajik, A.J.; Sadayappan, S. Hypertrophic cardiomyopathy clinical phenotype is independent of gene mutation and mutation dosage. PLoS ONE 2017, 12. [CrossRef]

3. Branzi, A.; Romeo, G.; Specchia, S.; Lolli, C.; Binetti, G.; Devoto, M.; Bacchi, M.; Magnani, B. Genetic heterogeneity of hypertrophic cardiomyopathy. Int. J. Cardiol. 1985, 7, 129-133. [CrossRef]

4. Hartmannova, H.; Kubanek, M.; Sramko, M.; Piherova, L.; Noskova, L.; Hodanova, K.; Stranecky, V.; Pristoupilova, A.; Sovova, J.; Marek, T.; et al. Isolated X-linked hypertrophic cardiomyopathy caused by a novel mutation of the four-and-a-half LIM domain 1 gene. Circ. Cardiovasc. Genet. 2013, 6, 543-551. [CrossRef] [PubMed]

5. Zamorano, J.L.; Anastasakis, A.; Borger, M.A.; Borggrefe, M.; Cecchi, F.; Charron, P.; Hagege, A.A.; Lafont, A.; Limongelli, G.; Mahrholdt, H.; et al. 2014 ESC guidelines on diagnosis and management of hypertrophic cardiomyopathy: The task force for the diagnosis and management of hypertrophic cardiomyopathy of the European Society of Cardiology (ESC). Eur. Heart J. 2014, 35, 2733-2779. [CrossRef]

6. Baxi, A.J.; Restrepo, C.S.; Vargas, D.; Marmol-Velez, A.; Ocazionez, D.; Murillo, H. Hypertrophic cardiomyopathy from A to Z: Genetics, pathophysiology, imaging, and management. Radiographics 2016, 36, 335-354. [CrossRef]

7. Maron, B.J.; Mathenge, R.; Casey, S.A.; Poliac, L.C.; Longe, T.F. Clinical profile of hypertrophic cardiomyopathy identified de novo in rural communities. J. Am. Coll. Cardiol. 1999, 33, 1590-1595. [CrossRef]

8. Hada, Y.; Sakamoto, T.; Amano, K.; Yamaguchi, T.; Takenaka, K.; Takahashi, H.; Takikawa, R.; Hasegawa, I.; Takahashi, T.; Suzuki, J.I.; et al. Prevalence of hypertrophic cardiomyopathy in a population of adult japanese workers as detected by echocardiographic screening. Am. J. Cardiol. 1987, 59, 183-184. [CrossRef]

9. Zou, Y.; Song, L.; Wang, Z.; Ma, A.; Liu, T.; Gu, H.; Lu, S.; Wu, P.; Zhang, Y.; Shen, L.; et al. Prevalence of idiopathic hypertrophic cardiomyopathy in China: A population-based echocardiographic analysis of 8080 adults. Am. J. Med. 2004, 116, 14-18. [CrossRef]

10. Naidoo, N.; Bajwa, G.; Duvuru, R.; Banerjee, Y. Thanatogenomic investigation of the hydroxymethylome and mitochondrial genome of cadaveric cardiomyocytes: Proposal for a proof-of-concept study. JMIR Res. Protoc. 2020, 9, e17241. [CrossRef] [PubMed]

11. Bick, A.G.; Flannick, J.; Ito, K.; Cheng, S.; Vasan, R.S.; Parfenov, M.G.; Herman, D.S.; Depalma, S.R.; Gupta, N.; Gabriel, S.B.; et al. Burden of rare sarcomere gene variants in the framingham and jackson heart study cohorts. Am. J. Hum. Genet. 2012, 91, 513-519. [CrossRef] [PubMed]

12. Maron, B.J.; Peterson, E.E.; Maron, M.S.; Peterson, J.E. Prevalence of hypertrophic cardiomyopathy in an outpatient population referred for echocardiographic study. Am. J. Cardiol. 1994, 73, 577-580. [CrossRef]

13. Semsarian, C.; Ingles, J.; Maron, M.S.; Maron, B.J. New perspectives on the prevalence of hypertrophic cardiomyopathy. J. Am. Coll. Cardiol. 2015, 65, 1249-1254. [CrossRef] [PubMed]

14. Morita, H.; Rehm, H.L.; Menesses, A.; McDonough, B.; Roberts, A.E.; Kucherlapati, R.; Towbin, J.A.; Seidman, J.G.; Seidman, C.E. Shared Genetic Causes of Cardiac Hypertrophy in Children and Adults. N Engl. J. Med. 2008, 358, 1899-1908. [CrossRef] [PubMed]

15. Tester, D.J.; Ackerman, M.J. Genetic testing for potentially lethal, highly treatable inherited cardiomyopathies/channelopathies in clinical practice. Circulation 2011, 123, 1021-1037. [CrossRef]

16. Maron, B.J.; Maron, M.S. Hypertrophic cardiomyopathy. Lancet 2013, 381, 242-255. [CrossRef]

17. Alcalai, R.; Seidman, J.G.; Seidman, C.E. Genetic basis of hypertrophic cardiomyopathy: From bench to the clinics. J. Cardiovasc. Electrophysiol. 2008, 19, 104-110. [CrossRef]

18. Maron, B.J.; Maron, M.S.; Semsarian, C. Genetics of hypertrophic cardiomyopathy after 20 years: Clinical perspectives. J. Am. Coll. Cardiol. 2012, 60, 705-715. [CrossRef]

19. Marian, A.J. Molecular Genetic Basis of Hypertrophic Cardiomyopathy. Circ. Res. 2021, 128, 1533-1553. [CrossRef]

20. Richard, P.; Charron, P.; Carrier, L.; Ledeuil, C.; Cheav, T.; Pichereau, C.; Benaiche, A.; Isnard, R.; Dubourg, O.; Burban, M.; et al Hypertrophic cardiomyopathy: Distribution of disease genes, spectrum of mutations, and implications for a molecular diagnosis strategy. Circulation 2003, 107, 2227-2232. [CrossRef]

21. Girolami, F.; Olivotto, I.; Passerini, I.; Zachara, E.; Nistri, S.; Re, F.; Fantini, S.; Baldini, K.; Torricelli, F.; Cecchi, F. A molecular screening strategy based on $\beta$-myosin heavy chain, cardiac myosin binding protein $\mathrm{C}$ and troponin $\mathrm{T}$ genes in Italian patients with hypertrophic cardiomyopathy. J. Cardiovasc. Med. 2006, 7, 601-607. [CrossRef] [PubMed] 
22. Weissler-Snir, A.; Hindieh, W.; Gruner, C.; Fourey, D.; Appelbaum, E.; Rowin, E.; Care, M.; Lesser, J.R.; Haas, T.S.; Udelson, J.E.; et al. Lack of Phenotypic Differences by Cardiovascular Magnetic Resonance Imaging in MYH7 ( $\beta$-Myosin Heavy Chain)Versus MYBPC3 (Myosin-Binding Protein C)-Related Hypertrophic Cardiomyopathy. Circ. Cardiovasc. Imaging 2017, 10, e005311. [CrossRef]

23. Hershberger, R.E.; Norton, N.; Morales, A.; Li, D.; Siegfried, J.D.; Gonzalez-Quintana, J. Coding sequence rare variants identified in MYBPC3, MYH6, TPM1, TNNC1, and TNNI3 from 312 patients with familial or idiopathic dilated cardiomyopathy. Circ. Cardiovasc. Genet. 2010, 3, 155-161. [CrossRef]

24. Liu, W.; Liu, W.; Hu, D.; Zhu, T.; Ma, Z.; Yang, J.; Xie, W.; Li, C.; Li, L.; Yang, J.; et al. Mutation spectrum in a large cohort of unrelated chinese patients with hypertrophic cardiomyopathy. Am. J. Cardiol. 2013, 112, 585-589. [CrossRef]

25. Ingles, J.; Goldstein, J.; Thaxton, C.; Caleshu, C.; Corty, E.W.; Crowley, S.B.; Dougherty, K.; Harrison, S.M.; McGlaughon, J.; Milko, L.V.; et al. Evaluating the Clinical Validity of Hypertrophic Cardiomyopathy Genes. Circ. Genomic Precis. Med. 2019, 12, 57-64. [CrossRef]

26. Mademont-Soler, I.; Mates, J.; Yotti, R.; Espinosa, M.A.; Pérez-Serra, A.; Fernandez-Avila, A.I.; Coll, M.; Méndez, I.; Iglesias, A.; Del Olmo, B.; et al. Additional value of screening for minor genes and copy number variants in hypertrophic cardiomyopathy. PLoS ONE 2017, 12, e0181465. [CrossRef]

27. Cirino, A.L.; Ho, C. Hypertrophic Cardiomyopathy Overview. In GeneReviews@; University of Washington: Seattle, DC, USA, 1993.

28. Micheu, M.M.; Popa-Fotea, N.-M.; Oprescu, N.; Bogdan, S.; Dan, M.; Deaconu, A.; Dorobantu, L.; Gheorghe-Fronea, O.; Greavu, M.; Iorgulescu, C.; et al. Yield of Rare Variants Detected by Targeted Next-Generation Sequencing in a Cohort of Romanian Index Patients with Hypertrophic Cardiomyopathy. Diagnostics 2020, 10, 1061. [CrossRef]

29. Roma-Rodrigues, C.; Fernandes, A.R. Genetics of hypertrophic cardiomyopathy: Advances and pitfalls in molecular diagnosis and therapy. Appl. Clin. Genet. 2014, 7, 195-208. [CrossRef] [PubMed]

30. Otsuka, H.; Arimura, T.; Abe, T.; Kawai, H.; Aizawa, Y.; Kubo, T.; Kitaoka, H.; Nakamura, H.; Nakamura, K.; Okamoto, H.; et al. Prevalence and distribution of sarcomeric gene mutations in Japanese patients with familial hypertrophic cardiomyopathy. Circ. J. 2012, 76, 453-461. [CrossRef]

31. Sankaranarayanan, R.; Fleming, E.J.; Garratt, C.J. Mimics of Hypertrophic Cardiomyopathy-Diagnostic Clues to Aid Early Identification of Phenocopies. Arrhythmia. Electrophysiol. Rev. 2013, 2, 36. [CrossRef] [PubMed]

32. Dahariya, S.; Paddibhatla, I.; Kumar, S.; Raghuwanshi, S.; Pallepati, A.; Gutti, R.K. Long non-coding RNA: Classification, biogenesis and functions in blood cells. Mol. Immunol. 2019, 112, 82-92. [CrossRef]

33. Lorenzen, J.M.; Thum, T. Long noncoding RNAs in kidney and cardiovascular diseases. Nat. Rev. Nephrol. 2016, 12, 360-373. [CrossRef]

34. Wang, K.C.; Chang, H.Y. Molecular Mechanisms of Long Noncoding RNAs. Mol. Cell 2011, 43, 904-914. [CrossRef]

35. Nelson, B.R.; Makarewich, C.A.; Anderson, D.M.; Winders, B.R.; Troupes, C.D.; Wu, F.; Reese, A.L.; McAnally, J.R.; Chen, X.; Kavalali, E.T.; et al. Muscle physiology: A peptide encoded by a transcript annotated as long noncoding RNA enhances SERCA activity in muscle. Science 2016, 351, 271-275. [CrossRef]

36. Huang, J.Z.; Chen, M.; Chen, D.; Gao, X.C.; Zhu, S.; Huang, H.; Hu, M.; Zhu, H.; Yan, G.R. A Peptide Encoded by a Putative lncRNA HOXB-AS3 Suppresses Colon Cancer Growth. Mol. Cell. 2017, 68, 171-184.e6. [CrossRef]

37. Choi, S.W.; Kim, H.W.; Nam, J.W. The small peptide world in long noncoding RNAs. Brief. Bioinform. 2019, $20,1853-1864$. [CrossRef] [PubMed]

38. Matsumoto, A.; Pasut, A.; Matsumoto, M.; Yamashita, R.; Fung, J.; Monteleone, E.; Saghatelian, A.; Nakayama, K.I.; Clohessy, J.G.; Pandolfi, P.P. MTORC1 and muscle regeneration are regulated by the LINC00961-encoded SPAR polypeptide. Nature 2017, 541, 228-232. [CrossRef]

39. Marchese, F.P.; Raimondi, I.; Huarte, M. The multidimensional mechanisms of long noncoding RNA function. Genome Biol. 2017, 18, 206. [CrossRef] [PubMed]

40. Salviano-Silva, A.; Lobo-Alves, S.C.; de Almeida, R.C.; Malheiros, D.; Petzl-Erler, M.L. Besides pathology: Long non-coding RNA in cell and tissue homeostasis. Non Coding RNA 2018, 4, 3. [CrossRef]

41. Fernandes, J.C.R.; Acuña, S.M.; Aoki, J.I.; Floeter-Winter, L.M.; Muxel, S.M. Long non-coding RNAs in the regulation of gene expression: Physiology and disease. Non Coding RNA 2019, 5, 17. [CrossRef] [PubMed]

42. Arun, G.; Diermeier, S.D.; Spector, D.L. Therapeutic Targeting of Long Non-Coding RNAs in Cancer. Trends Mol. Med. 2018, 24, 257-277. [CrossRef] [PubMed]

43. Zhang, Y.; Du, W.; Yang, B. Long non-coding RNAs as new regulators of cardiac electrophysiology and arrhythmias: Molecular mechanisms, therapeutic implications and challenges. Pharmacol. Ther. 2019, 203, 107389. [CrossRef] [PubMed]

44. Cai, B.; Zhang, Y.; Zhao, Y.; Wang, J.; Li, T.; Zhang, Y.; Jiang, Y.; Jin, X.; Xue, G.; Li, P.; et al. Long Noncoding RNA-DACH1 (Dachshund Homolog 1) Regulates Cardiac Function by Inhibiting SERCA2a (Sarcoplasmic Reticulum Calcium ATPase 2a). Hypertension 2019, 74, 833-842. [CrossRef] [PubMed]

45. Liu, S.; Zhao, M.; Zhou, Y.; Wang, C.; Yuan, Y.; Li, L.; Bresette, W.; Chen, Y.; Cheng, J.; Lu, Y.; et al. Resveratrol exerts dose-dependent anti-fibrotic or pro-fibrotic effects in kidneys: A potential risk to individuals with impaired kidney function. Phytomedicine 2019, 57, 223-235. [CrossRef] 
46. Lv, L.; Li, T.; Li, X.; Xu, C.; Liu, Q.; Jiang, H.; Li, Y.; Liu, Y.; Yan, H.; Huang, Q.; et al. The lncRNA Plscr4 Controls Cardiac Hypertrophy by Regulating miR-214. Mol. Ther. Nucleic Acids 2018, 10, 387-397. [CrossRef] [PubMed]

47. Viereck, J.; Kumarswamy, R.; Foinquinos, A.; Xiao, K.; Avramopoulos, P.; Kunz, M.; Dittrich, M.; Maetzig, T.; Zimmer, K.; Remke, J.; et al. Long noncoding RNA Chast promotes cardiac remodeling. Sci. Transl. Med. 2016, 8, 1475. [CrossRef]

48. Wang, K.; Liu, F.; Zhou, L.Y.; Long, B.; Yuan, S.M.; Wang, Y.; Liu, C.Y.; Sun, T.; Zhang, X.J.; Li, P.F. The long noncoding RNA CHRF regulates cardiac hypertrophy by targeting miR-489. Circ. Res. 2014, 114, 1377-1388. [CrossRef]

49. Li, Y.; Wang, J.; Sun, L.; Zhu, S. LncRNA myocardial infarction-associated transcript (MIAT) contributed to cardiac hypertrophy by regulating TLR4 via miR-93. Eur. J. Pharmacol. 2018, 818, 508-517. [CrossRef]

50. Li, Z.; Liu, Y.; Guo, X.; Sun, G.; Ma, Q.; Dai, Y.; Zhu, G.; Sun, Y. Long noncoding RNA myocardial infarction-associated transcript is associated with the microRNA-150-5p/P300 pathway in cardiac hypertrophy. Int. J. Mol. Med. 2018, 42, 1265-1272. [CrossRef]

51. Wang, Z.; Zhang, X.J.; Ji, Y.X.; Zhang, P.; Deng, K.Q.; Gong, J.; Ren, S.; Wang, X.; Chen, I.; Wang, H.; et al. The long noncoding RNA Chaer defines an epigenetic checkpoint in cardiac hypertrophy. Nat. Med. 2016, 22, 1131-1139. [CrossRef]

52. Lai, Y.; He, S.; Ma, L.; Lin, H.; Ren, B.; Ma, J.; Zhu, X.; Zhuang, S. HOTAIR functions as a competing endogenous RNA to regulate PTEN expression by inhibiting miR-19 in cardiac hypertrophy. Mol. Cell. Biochem. 2017, 432, 179-187. [CrossRef] [PubMed]

53. Jiang, F.; Zhou, X.; Huang, J. Long non-coding RNA-ROR mediates the reprogramming in cardiac hypertrophy. PLoS ONE 2016, 11, e0152767. [CrossRef]

54. Yang, X.; Tao, L.; Zhu, J.; Zhang, S. Long noncoding RNA FTX reduces hypertrophy of neonatal mouse cardiac myocytes and regulates the PTEN/PI3K/Akt signaling pathway by sponging MicroRNA-22. Med. Sci. Monit. 2019, 25, 9609-9617. [CrossRef] [PubMed]

55. Zhang, J.; Liang, Y.; Huang, X.; Guo, X.; Liu, Y.; Zhong, J.; Yuan, J. STAT3-induced upregulation of lncRNA MEG3 regulates the growth of cardiac hypertrophy through miR-361-5p/HDAC9 axis. Sci. Rep. 2019, 9, s41598-018. [CrossRef]

56. Wang, Y.; Cao, R.; Yang, W.; Qi, B. SP1-SYNE1-AS1-miR-525-5p feedback loop regulates Ang-II-induced cardiac hypertrophy. J. Cell. Physiol. 2019, 234, 14319-14329. [CrossRef]

57. Zhang, M.; Gu, H.; Chen, J.; Zhou, X. Involvement of long noncoding RNA MALAT1 in the pathogenesis of diabetic cardiomyopathy. Int. J. Cardiol. 2016, 202, 753-755. [CrossRef] [PubMed]

58. Peters, T.; Hermans-Beijnsberger, S.; Beqqali, A.; Bitsch, N.; Nakagawa, S.; Prasanth, K.V.; De Windt, L.J.; Van Oort, R.J.; Heymans, S.; Schroen, B. Long non-coding RNA malat-1 is dispensable during pressure overload-induced cardiac remodeling and failure in mice. PLoS ONE 2016, 11. [CrossRef]

59. Xu, L.; Wang, H.; Jiang, F.; Sun, H.; Zhang, D. LncRNA AK045171 protects the heart from cardiac hypertrophy by regulating the SP1/MG53 signalling pathway. Aging 2020, 12, 3126-3139. [CrossRef]

60. Shao, M.; Chen, G.; Lv, F.; Liu, Y.; Tian, H.; Tao, R.; Jiang, R.; Zhang, W.; Zhuo, C. LncRNA TINCR attenuates cardiac hypertrophy by epigenetically silencing CaMKII. Oncotarget 2017, 8, 47565-47573. [CrossRef]

61. Zhou, G.; Li, C.; Feng, J.; Zhang, J.; Fang, Y. LncRNA UCA1 Is a novel regulator in cardiomyocyte hypertrophy through targeting the miR-184/HOXA9 axis. CardioRenal Med. 2018, 8, 130-139. [CrossRef] [PubMed]

62. Xiao, L.; Gu, Y.; Sun, Y.; Chen, J.; Wang, X.; Zhang, Y.; Gao, L.; Li, L. The long noncoding RNA XIST regulates cardiac hypertrophy by targeting miR-101. J. Cell. Physiol. 2019, 234, 13680-13692. [CrossRef] [PubMed]

63. Chen, Y.; Liu, X.; Chen, L.; Chen, W.; Zhang, Y.; Chen, J.; Wu, X.; Zhao, Y.; Wu, X.; Sun, G. The long noncoding RNA XIST protects cardiomyocyte hypertrophy by targeting miR-330-3p. Biochem. Biophys. Res. Commun. 2018, 505, 807-815. [CrossRef]

64. Zou, X.; Wang, J.; Tang, L.; Wen, Q. LncRNA TUG1 contributes to cardiac hypertrophy via regulating miR-29b-3p. Vitr. Cell. Dev. Biol. Anim. 2019, 55, 482-490. [CrossRef] [PubMed]

65. Fang, Q.; Liu, T.; Yu, C.; Yang, X.; Shao, Y.; Shi, J.; Ye, X.; Zheng, X.; Yan, J.; Xu, D. LncRNA TUG1 alleviates cardiac hypertrophy by targeting miR-34a/DKK1/Wnt- $\beta$-catenin signalling. J. Cell. Mol. Med. 2020, 24, 3678-3691. [CrossRef]

66. Li, C.; Zhou, G.; Feng, J.; Zhang, J.; Hou, L.; Cheng, Z. Upregulation of lncRNA VDR/CASC15 induced by facilitates cardiac hypertrophy through modulating miR-432-5p/TLR4 axis. Biochem. Biophys. Res. Commun. 2018, 503, 2407-2414. [CrossRef]

67. Yuan, Y.; Wang, J.; Chen, Q.; Wu, Q.; Deng, W.; Zhou, H.; Shen, D. Long non-coding RNA cytoskeleton regulator RNA (CYTOR) modulates pathological cardiac hypertrophy through miR-155-mediated IKKi signaling. Biochim. Biophys. Acta Mol. Basis Dis. 2019, 1865, 1421-1427. [CrossRef]

68. Yu, Y.H.; Hu, Z.Y.; Li, M.H.; Li, B.; Wang, Z.M.; Chen, S.L. Cardiac hypertrophy is positively regulated by long non-coding RNA PVT1. Int. J. Clin. Exp. Pathol. 2015, 8, 2582-2589. [PubMed]

69. Zhang, M.; Jiang, Y.; Guo, X.; Zhang, B.; Wu, J.; Sun, J.; Liang, H.; Shan, H.; Zhang, Y.; Liu, J.; et al. Long non-coding RNA cardiac hypertrophy-associated regulator governs cardiac hypertrophy via regulating miR-20b and the downstream PTEN/AKT pathway. J. Cell. Mol. Med. 2019, 23, 7685-7698. [CrossRef]

70. Chen, Y.; Zhang, Z.; Zhu, D.; Zhao, W.; Li, F. Knockdown of KCNQ1OT1 attenuates cardiac hypertrophy through modulation of the miR-2054/AKT3 axis. J. Thorac. Dis. 2020, 12, 4771-4780. [CrossRef]

71. Cheng, Z.; Liu, L.; Li, Q. IncRNA ZEB2-AS1 stimulates cardiac hypertrophy by downregulating PTEN. Exp. Ther. Med. 2020, 20, 9220. [CrossRef]

72. Wen, Z.Q.; Li, S.H.; Shui, X.; Tang, L.L.; Zheng, J.R.; Chen, L. LncRNA PEG10 aggravates cardiac hypertrophy through regulating HOXA9. Eur. Rev. Med. Pharmacol. Sci. 2021, 23, 281-286. [CrossRef] 
73. Sun, X.L.; Lv, J.L.; Dou, L.; Chen, D.; Zhu, Y.C.; Hu, X. LncRNA NEAT1 promotes cardiac hypertrophy through microRNA-19a3p/SMYD2 axis. Eur. Rev. Med. Pharmacol. Sci. 2020, 24, 1367-1377. [CrossRef]

74. Yu, J.; Yang, Y.; Xu, Z.; Lan, C.; Chen, C.; Li, C.; Chen, Z.; Yu, C.; Xia, X.; Liao, Q.; et al. Long Noncoding RNA Ahit Protects against Cardiac Hypertrophy through SUZ12 (Suppressor of Zeste 12 Protein Homolog)-Mediated Downregulation of MEF2A (Myocyte Enhancer Factor 2A). Circ. Hear. Fail. 2020, 13, 6525. [CrossRef]

75. Song, C.; Qi, H.; Liu, Y.; Chen, Y.; Shi, P.; Zhang, S.; Ren, J.; Wang, L.; Cao, Y.; Sun, H. Inhibition of lncRNA Gm15834 Attenuates Autophagy-Mediated Myocardial Hypertrophy via the miR-30b-3p/ULK1 Axis in Mice. Mol. Ther. 2021, 29, 1120-1137. [CrossRef] [PubMed]

76. Wang, L.; Wang, J.; Li, G.; Xiao, J. Non-coding RNAs in Physiological Cardiac Hypertrophy. Adv. Exp. Med. Biol. 2020, 1229, 149-161. [CrossRef] [PubMed]

77. Sun, J.; Wang, C. Long non-coding RNAs in cardiac hypertrophy. Heart Fail. Rev. 2020, 25, 1037-1045. [CrossRef] [PubMed]

78. Kastner, N.; Zlabinger, K.; Spannbauer, A.; Traxler, D.; Mester-Tonczar, J.; Hašimbegović, E.; Gyöngyösi, M. New Insights and Current Approaches in Cardiac Hypertrophy Cell Culture, Tissue Engineering Models, and Novel Pathways Involving Non-Coding RNA. Front. Pharmacol. 2020, 11, 1314. [CrossRef]

79. Liu, L.; Zhang, D.; Li, Y. LncRNAs in cardiac hypertrophy: From basic science to clinical application. J. Cell. Mol. Med. 2020, 24, 11638-11645. [CrossRef]

80. Hobuß, L.; Bär, C.; Thum, T. Long non-coding RNAs: At the heart of cardiac dysfunction? Front. Physiol. 2019, 10, 30. [CrossRef]

81. Gómez, J.; Lorca, R.; Reguero, J.R.; Martín, M.; Morís, C.; Alonso, B.; Iglesias, S.; Díaz-Molina, B.; Avanzas, P.; Coto, E. Genetic variation at the long noncoding RNA H19 gene is associated with the risk of hypertrophic cardiomyopathy. Epigenomics 2018, 10, 865-873. [CrossRef]

82. Zhou, J.; Zhou, Y.; Wang, C. xia LncRNA-MIAT regulates fibrosis in hypertrophic cardiomyopathy (HCM) by mediating the expression of miR-29a-3p. J. Cell. Biochem. 2019, 120, 7265-7275. [CrossRef] [PubMed]

83. Han, P.; Li, W.; Lin, C.H.; Yang, J.; Shang, C.; Nurnberg, S.T.; Jin, K.K.; Xu, W.; Lin, C.Y.; Lin, C.J.; et al. A long noncoding RNA protects the heart from pathological hypertrophy. Nature 2014, 514, 102-106. [CrossRef]

84. Wu, D.; Zhou, Y.; Fan, Y.; Zhang, Q.; Gu, F.; Mao, W.; Zhang, M. LncRNA CAIF was downregulated in end-stage cardiomyopathy and is a promising diagnostic and prognostic marker for this disease. Biomarkers 2019, 24, 735-738. [CrossRef] [PubMed]

85. Kitow, J.; Derda, A.A.; Beermann, J.; Kumarswarmy, R.; Pfanne, A.; Fendrich, J.; Lorenzen, J.M.; Iao, K.; Bavendiek, U.; Bauersachs, J.; et al. Mitochondrial long noncoding RNAs as blood based biomarkers for cardiac remodeling in patients with hypertrophic cardiomyopathy. Am. J. Physiol. Hear. Circ. Physiol. 2016, 311, H707-H712. [CrossRef] [PubMed]

86. Li, J.; Wu, Z.; Zheng, D.; Sun, Y.; Wang, S.; Yan, Y. Bioinformatics analysis of the regulatory lncRNA-miRNA-mRNA network and drug prediction in patients with hypertrophic cardiomyopathy. Mol. Med. Rep. 2019, 20, 549-558. [CrossRef]

87. Liu, X.; Ma, Y.; Yin, K.; Li, W.; Chen, W.; Zhang, Y.; Zhu, C.; Li, T.; Han, B.; Liu, X.; et al. Long non-coding and coding RNA profiling using strand-specific RNA-seq in human hypertrophic cardiomyopathy. Sci. Data 2019, 6, 90. [CrossRef]

88. Hu, X.; Shen, G.; Lu, X.; Ding, G.; Shen, L. Identification of key proteins and lncRNAs in hypertrophic cardiomyopathy by integrated network analysis. Arch. Med. Sci. 2019, 15, 484-497. [CrossRef]

89. Guo, Q.; Wang, J.; Sun, R.; Gu, W.; He, Z.; Chen, Q.; Liu, W.; Chen, Y.; Wang, J.; Zhang, Y. Identification of circulating hub long noncoding RNAs associated with hypertrophic cardiomyopathy using weighted correlation network analysis. Mol. Med. Rep. 2020, 22, 4637-4644. [CrossRef]

90. Yang, W.; Li, Y.; He, F.; Wu, H. Microarray profiling of long non-coding RNA (lncRNA) associated with hypertrophic cardiomyopathy. BMC Cardiovasc. Disord. 2015, 15, 62. [CrossRef]

91. Tao, L.; Shi, J.; Huang, X.; Hua, F.; Yang, L. Identification of a lncRNA-miRNA-mRNA network based on competitive endogenous RNA theory reveals functional lncRNAs in hypertrophic cardiomyopathy. Exp. Ther. Med. 2020, 20, 1176-1190. [CrossRef] 